\title{
Influence of the Asian monsoon on net ecosystem carbon exchange in two major ecosystems in Korea
}

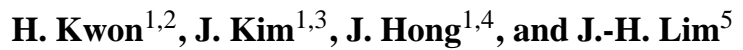 \\ ${ }^{1}$ Biometeorology Laboratory and Global Environment Laboratory, Department of Atmospheric Sciences, Yonsei University, \\ Seoul, 120-749, Korea \\ ${ }^{2}$ National Center for Agro-Meteorology, Colleage of Agriculture and Life Science, Seoul National University, \\ Seoul, 151-742, Korea \\ ${ }^{3}$ Global Center of Excellence for Sustainable Urban Regeneration, Institute of Industrial Science, The University of Tokyo, \\ Tokyo, 153-8505, Japan \\ ${ }^{4}$ National Institute for Mathematical Sciences, Daejoen, 305-702, Korea \\ ${ }^{5}$ Department of Forest Conservation, Korea Forest Research Institute, Seoul, 130-712, Korea
}

Received: 19 September 2009 - Published in Biogeosciences Discuss.: 5 November 2009

Revised: 3 April 2010 - Accepted: 17 April 2010 - Published: 12 May 2010

\begin{abstract}
Considering the feedback in radiation, temperature, and soil moisture with alterations in rainfall patterns, the influence of the changing monsoon on Net Ecosystem $\mathrm{CO}_{2}$ Exchange (NEE) can be critical to the estimation of carbon balance in Asia. In this paper, we examined $\mathrm{CO}_{2}$ fluxes measured by the eddy covariance method from 2004 to 2008 in two major ecosystems in the KoFlux sites in Korea, i.e., the Gwangneung Deciduous forest (GDK) and the Haenam Farmland (HFK). Our objectives were to identify the repeatability of the mid-season depression of NEE encountered at the two sites based on the single-year observation, and to further scrutinize its cause, effect, and interannual variability by using multi-year observations. In both GDK and HFK sites, the mid-season depression of NEE was reproduced each year but with different timing, magnitude, and mechanism. At the GDK site, a predominant factor causing the mid-season depression was a decreased solar radiation and the consequent reduction in Gross Primary Productivity (GPP) during the summer monsoon period. At the HFK site, however, the monsoonal effect was less pronounced and the apparent mid-season depression was mainly a result of the management practices such as cultivation of spring barley and rice transplantation. Other flux observation sites in East Asia also showed a decline in radiation but with a lesser degree during
\end{abstract}

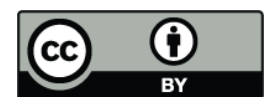

Correspondence to: H. Kwon (hyojungkwon@yonsei.ac.kr) the monsoon season, resulting in less pronounced depression in NEE. In our study, the observed depressions in NEE caused both GDK and HFK sites to become a weaker carbon sink or even a source in the middle of the growing season. On average, the GDK site (with maximum leaf area index of 5) was a weak carbon sink with NEE of $-84 \mathrm{gC} \mathrm{m}^{-2} \mathrm{y}^{-1}$. Despite about $20 \%$ larger GPP (of $1321 \mathrm{gC} \mathrm{m}^{-2} \mathrm{y}^{-1}$ ) in comparison with the GDK site, the HFK site (with maximum leaf area index of 3-4) was a weaker carbon sink with NEE of $-58 \mathrm{gC} \mathrm{m}^{-2} \mathrm{y}^{-1}$ because of greater ecosystem respiration (of $1263 \mathrm{gC} \mathrm{m}^{-2} \mathrm{y}^{-1}$ ). These NEE values were near the low end of the ranges reported in the literature for similar ecosystems in mid-latitudes. With the projected trends of the extended length of monsoon with more intensive rainfalls in East Asia, the observed delicate coupling between carbon and hydrological cycles may turn these key ecosystems into carbon neutral.

\section{Introduction}

The Asian continent is covered with diverse ecosystems from tropical forests to boreal forests and from temperate grasslands to deserts to tundra. It also contains agricultural lands including mixed croplands and rice paddies. These ecosystems explain about $20 \%$ of potential global terrestrial net primary productivity (Melillo et al., 1993; McGuire et al., 2001)

Published by Copernicus Publications on behalf of the European Geosciences Union. 


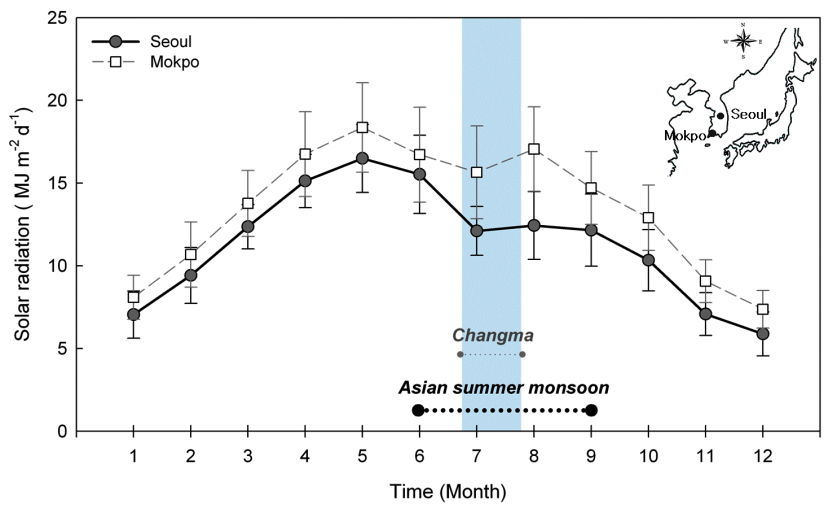

Fig. 1. Variations of 30-year (1971-2000) averaged daily solar radiation per month at Seoul and Mokpo in Korea. Seoul is located near the deciduous forest (the GDK site), while Mokpo is located near the farmland site (the HFK site).

and undergo rapid land use and cover change for economic developments. Under the current climate and environmental changes, one of the main concerns lies in the potential role of terrestrial ecosystems in Asia for global carbon balance.

The monsoon climate in Asia has been suggested as a major factor controlling carbon budget. Based on modeling results, Esser (1995) showed that the Asian monsoon region acted as a carbon source to the atmosphere due to land use changes since the mid 19th century. Fu and Wen (1999) reported that variation in monsoon climate had a strong correlation with Net Primary Production (NPP). Yang and Wang (2000) suggested that an increase of precipitation with enhanced clouds reduces seasonal NPP and causes a higher carbon emission. Considering the inter-connected changes in radiation, temperature, and soil moisture with alterations in precipitation, the influence of changing monsoon climate on carbon balance in Asia is critical to ascertain the regional and global carbon balance.

The Asian summer monsoon (June to August) is divided into three subsystems (i.e., Indian monsoon, East Asian monsoon, and western North Pacific monsoon) and the Korean Peninsular is under the subsystem of East Asian monsoon. During the monsoon period such as "Changma" (i.e., an intensive rainy period) and a subsequent typhoon season in Korea, the solar radiation is expected to decrease due to frequent and concentrated rainfalls. The climate normal (averaged for the 1971-2000 period) in solar radiation at two different latitudes in Korea shows a substantial decrease particularly in July during Changma (Fig. 1). Kwon et al. (2009) reported that such a reduced radiation caused a significant mid-season "depression" (i.e., reduction in magnitude) in Net Ecosystem carbon Exchange (NEE) in two major ecosystems (i.e., a deciduous forest and farmland) at these latitudes. Under the global warming scenarios, the precipitation during the East Asian monsoon is to be intensified (except a part of northern region) and the duration of Changma is expected to change with more intensive rainfalls in the Korean Peninsula (e.g., Yun et al., 2008). The likely changes in precipitation regime are expected to alter the feedback in carbon balance between the atmosphere and the ecosystems in East Asia.

Previous studies indicate diverse determinants controlling the interannual variations in ecosystem carbon budget in different climate regimes. For example, in a boreal conifer forest, Dum et al. (2007) reported that the interannual variability of carbon exchange was determined by the variations in water table elevation, soil temperature, and summertime solar radiation. The carbon budget of a moist tussock tundra in Alaska was strongly temperature dependent, accentuating the importance of ecosystem respiration (Kwon et al., 2006). In a sagebrush-steppe ecosystem, the interannual variability of NEE was linked to precipitation timing and amount of total annual precipitation (Gilmanov et al., 2006). In oak/grass savanna and grassland ecosystems, the length of the growing season was important (Ma et al., 2007). In an evergreen Mediterranean forest, the interannual variability of NEE was affected by drought and/or defoliation during March-June period (Allard et al., 2008).

In East Asia, based on almost a decade-long record of flux measurements in a deciduous forest, Saigusa et al. (2005) attributed the observed large interannual variations in carbon budget to those in radiation. The seasonal variation of carbon exchange at grazed steppe ecosystem in central Mongolia was closely associated with precipitation and soil moisture (Li et al., 2005). Hirata et al. (2007) ascribed the interannual variation of carbon budget to changes in radiation in the summer and temperature in the spring and summer. Despite the apparent influence of the summer monsoon, however, it is rare to find its clear impact seen in the seasonal and annual variations of NEE from the literature. This may have been due to the confounding effects of the controlling factors with rainfall changes on NEE, the difficulty in separating their roles, and potential errors in gap-filling of the missing fluxes for the rainy periods.

Based on a single year's flux observation in 2006, Kwon et al. (2009) reported a significant mid-season depression in NEE and Gross Primary Production (GPP) in both deciduous forest and farmland ecosystems in Korea. The consequent bimodal seasonality was attributed to different timing and intensity of the disturbances encountered during the summer monsoon, the passage of typhoons after Changma and the land use management (e.g., crop rotation). Our objectives were to identify the repeatability of the mid-season depression in NEE observed by Kwon et al. (2009) and to further scrutinize its cause, effect, and interannual variability by using multi-year observations in the same KoFlux tower sites reported in Kwon et al. (2009). Our hypothesis is that the driving mechanisms of the observed mid-season depressions of NEE are different for these two ecosystems. For the GDK forest site, natural disturbance (e.g., Changma and typhoons) is the major cause, whereas human disturbance (e.g., twocrop rotation) is dominant for the HFK farmland site. In 
order to verify the hypothesis, we conducted the analysis of the relationship among GPP, RE, and NEE, and environmental conditions.

We have extended the eddy covariance flux measurement and analysis from 2006 to 2008 for the deciduous forest site and added two more years' data (i.e., 2004 and 2008) for the farmland site. The years with data retrieval rate of $<40 \%$ (i.e., 2004 and 2005 for the GDK site and 2005 and 2007 for the HFK site) were excluded from our analysis to minimize the artifact of excessive gap-filling.

\section{Materials and methods}

\subsection{The study sites}

Measurements of $\mathrm{CO}_{2}$ flux were conducted at two KoFlux sites: the Gwangneung Deciduous forest (GDK) and the Haenam Farmland (HFK). The GDK site is located in the west-central part of the Korean Peninsular $\left(37^{\circ} 45^{\prime} 25.37^{\prime \prime} \mathrm{N}\right.$, $\left.127^{\circ} 9^{\prime} 11.62^{\prime \prime} \mathrm{E}, 90-470 \mathrm{~m} . \mathrm{s} .1.\right)$. This site is in a complex, hilly catchment with a mean slope of $10-20^{\circ}$. The fetch was about $1 \mathrm{~km}$ for the prevailing wind directions. The vegetation is dominated by an old natural forest of Quercus sp. and Carpinus sp. (80-200 years old) with a mean canopy height of $\sim 18 \mathrm{~m}$. Soil depth is 0.4 to $0.8 \mathrm{~m}$ and soil texture is mainly sandy loam (Lim et al., 2003). Further description of the GDK site can be found in Lee et al. (2007).

The HFK site is located near the southwestern coast of the Korean Peninsula $\left(34^{\circ} 33^{\prime} 17.70^{\prime \prime} \mathrm{N}, 126^{\circ} 34^{\prime} 7.11^{\prime \prime} \mathrm{E}\right.$, 13.74 m.s.l.) with heterogeneous land cover types consisting of rice paddies and a different patch of various land use (Moon et al., 2007). The terrain of the surrounding areas of the flux tower was flat. Around the tower (e.g., within the flux footprint of $\sim 300 \mathrm{~m}$ ) is predominantly rice paddies with mosaic patches of farmland, similar to the regional land covers except roads and small mountains.

\subsection{Field measurements}

Eddy covariance technique was used to measure $\mathrm{CO}_{2}$ flux from a $40 \mathrm{~m}$ tower at the GDK site and a $20 \mathrm{~m}$ tower at the HFK. The fluctuations in wind velocity (e.g., vertical, streamwise, and lateral wind speed) and temperature were measured with a three-dimensional sonic anemometer (Model CSAT3, Campbell Scientific Inc., Logan, Utah, USA) at $10 \mathrm{~Hz}$ sampling rates for both sites. To measure the fluctuations in $\mathrm{CO}_{2}$ concentration, an open-path infrared gas analyzer (IRGA; Model LI-7500, LI-COR Inc., Lincoln, Nebraska, USA) was used for both sites. Half-hourly eddy covariances and the associated statistics were calculated online from $10 \mathrm{~Hz}$ raw data and stored on the dataloggers (Model CR-5000, Campbell Scientific Inc.). Other measurements were also conducted and logged in the dataloggers (Model CR-23X and CR-5000 at the GDK site and CR-5000 at the HFK site, Campbell Scientific Inc.). Net radiation $\left(R_{\mathrm{n}}\right)$ was measured using a net radiometer (Model CNR1, Kipp \& Zonen, Delft, the Netherlands) at $40 \mathrm{~m}$ for the GDK site and $15 \mathrm{~m}$ for the HFK site. Air temperature $\left(T_{\mathrm{a}}\right)$ and relative humidity $(\mathrm{RH})$ were measured with a thermistor and capacitive RH probe (Model HMP45C, Vaisala Inc., Helsinki, Finland) at various heights for the GDK site. Soil temperature $\left(T_{\mathrm{s}}\right)$ was measured at both sites with soil temperature probes (Model TCAV, Campbell Scientific Inc.) at a depth of $10 \mathrm{~cm}$. Soil moisture (SWC) was measured using soil moisture probe (Model CS616, Campbell Scientific Inc.) from 0 to $10 \mathrm{~cm}$ at both sites. Ground heat flux $(G)$ was measured at $10 \mathrm{~cm}$ at both sites using ground heat flux plates (Model HFP01SC, REBS, Seattle, USA) at different locations. At the HFK site, the measurements of $T_{\mathrm{S}}, \mathrm{SWC}$, and $G$ were conducted in farmland areas. More information can be found in Lee et al. (2007), Kwon et al. (2009), and the KoFlux website (http://koflux.org).

In order to determine the climatological characteristics of the studied years for each site, the 30-year normals (averaged for 1971-2000) for solar radiation, air temperature, and precipitation were estimated by interpolation for the GDK site using the closest weather station (KMA \#108) using halfhourly data. For the HFK site, the temperature and precipitation normals were obtained directly from the on-site weather station (KMA \#261) except solar radiation, which was estimated from the closest weather station (KMA \#165). The estimates from the nearby weather stations and the on-site measurements were in good agreement. For example, the relationship between solar radiation from KMA \#165 weather station $\left(\mathrm{X}_{\mathrm{KMA}}\right)$ and that from the tower at the HFK site $\left(\mathrm{Y}_{\mathrm{HFK}}\right)$ was $\mathrm{Y}_{\mathrm{HFK}}=0.93 \mathrm{X}_{\mathrm{KMA}}+8$ with $r^{2}$ of 0.91 for 2008 .

\subsection{Leaf area measurements}

The measurements of the Plant Area Index (PAI) was conducted every two or three weeks at the GDK site using plant canopy analyzers (Model LAI-2000, LI-COR Inc.) under diffuse light conditions at 12 sampling points with 50 x $50 \mathrm{~m}$ grid interval. The PAI measurements were not conducted at the HFK site. Instead, the $1 \mathrm{~km}$ global data product from moderate-resolution imaging spectroradiometer (MODIS) was used to illustrate the annual pattern of leaf area index (LAI; Myneni et al., 2002; https://lpdaac.usgs. gov/lpdaac/products/modis_products_table). The additional information (on cloud, aerosol, overall product quality, etc.) provided with MODIS LAI was utilized for quality control.

\subsection{Data processing, quality control, and gap-filling}

The eddy covariance data were reprocessed, qualitycontrolled, and then gap-filled using the standardized KoFlux protocol (Hong et al., 2009), which is similar to that of FLUXNET (Papale et al., 2006). The standardized protocol includes Planar Fit Rotation (PFR), WPL correction, spike detection, storage correction, nighttime correction, 
gap-filling, and the estimation of GPP and Ecosystem Respiration (RE). The PFR was applied to determine the angles necessary to place the sonic anemometer into a streamwise coordinate system (Wilczak et al., 2001; Yuan et al., 2007). In order to consider the effect of rolling topography around the flux towers, the PFR was applied to each $30^{\circ}$ of wind direction sectors. The flux was corrected for the variation in air density due to simultaneous transfers of water vapor and sensible heat (Webb et al., 1980). The method by van Gorse et al. (2007) was applied during calm conditions when advection was relatively negligible. The vertical and horizontal advections at the GDK site were not small in size but their signs were opposite, thereby approximately canceling each other out. We made an assumption that the advection effect was negligible at the site, which of course is subject to further scrutiny.

After the quality control, the data retrieval rate was $52 \sim 74 \%$ at the GDK site and $55 \sim 85 \%$ at the HFK site during the study period. In order to fill the missing $\mathrm{CO}_{2}$ fluxes, the meteorological data were prefilled. At the GDK site, solar radiation $\left(R_{\mathrm{g}}\right)$, air temperature $\left(T_{\mathrm{a}}\right)$, Vapor Pressure Deficit (VPD), and wind speed were filled from the linear relationships with either the auxiliary data observed at the site or the data observed at the second tower $(\sim 1.2 \mathrm{~km}$ apart). The meteorological data at the HFK site were filled with the data from the KMA weather station at the site. For storage correction for $\mathrm{CO}_{2}$ flux calculation (Papale et al., 2006; Kwon et al., 2009), the $\mathrm{CO}_{2}$ concentration data from an open-path IRGA were gap-filled using those measured simultaneously by the profile system (i.e., a closedpath system, Model LI-6262, LI-COR; Yoo et al., 2009) at the GDK site. The mean diurnal variation method was used to fill the gaps of the $\mathrm{CO}_{2}$ concentration at the HFK site because no additional $\mathrm{CO}_{2}$ concentration measurements were available. The storage fluxes calculated from $\mathrm{CO}_{2}$ concentration data by the open-path IRGA and by the profile system at eight levels showed a good agreement (e.g., $\mathrm{Y}_{\text {PROFILE }}=0.82 \mathrm{X}_{\mathrm{OPEN}-\mathrm{PATH}}+0.05 ; r^{2}=0.57$ for 2006) at the GDK site. In order for the consistency of data selection and processing, however, we used $\mathrm{CO}_{2}$ concentration data from the open-path IRGA for both sites to calculate a storage term, following Papale et al. (2006).

Spike detection was conducted and then storage correction was applied to the $\mathrm{CO}_{2}$ flux dataset, following $\mathrm{Pa}-$ pale et al. (2006). Gap-filling was performed for nighttime $\left(R_{\mathrm{g}}<1 \mathrm{~W} \mathrm{~m}^{-2}\right)$ and daytime $\left(R_{\mathrm{g}} \geq 1 \mathrm{~W} \mathrm{~m}^{-2}\right)$ data separately. Instead of using the $u^{*}$-threshold filtering technique (e.g., $\mathrm{Gu}$ et al., 2005; Reichstein et al., 2005), we adopted the method suggested by van Gorsel et al. (2007) to estimate nighttime $\mathrm{CO}_{2}$ flux (RE). This method selects the maximum nocturnal $\mathrm{CO}_{2}$ flux (i.e., $\mathrm{RE}_{\max }$ ) in the early evening when the sum of the turbulent flux and change in storage of $\mathrm{CO}_{2}$ becomes maximum and the advection is relatively negligible. The $\mathrm{RE}_{\max }$ was used to derive a temperature response function for the $\mathrm{CO}_{2}$ fluxes. In this study, the $\mathrm{RE}_{\max }$ occurred mostly from 18:00 to $20: 00 \mathrm{~h}$ and all the available $\mathrm{RE}_{\max }$ data and $T_{\mathrm{a}}$ over a fixed period (e.g., 20 days for the GDK site and 32 days for the HFK site) were used to estimate RE using the exponential regression model of Lloyd and Taylor (1994). The two different window sizes for the model run were decided based on the spectra of $T_{\mathrm{a}}$ and they corresponded to the location of spectral gaps between the second and third peaks in the spectra of $T_{\mathrm{a}}$.

Marginal Distribution Sample (MDS), which is an advanced look-up table method, was used to do the gap-filling for the daytime $\mathrm{CO}_{2}$ data (Reichstein et al., 2005). NEE data were binned by meteorological variables controlling NEE such as net radiation $\left(R_{\mathrm{n}}\right), T_{\mathrm{a}}$, and VPD over a time-window with the same number of days used for RE estimation. The binning intervals for the variables were $40 \mathrm{~W} \mathrm{~m}^{-2}$ for $R_{\mathrm{n}}$, $2.5^{\circ} \mathrm{C}$ for $T_{\mathrm{a}}$, and $0.5 \mathrm{kPa}$ for VPD. When there was a missing NEE value, it was replaced with the binned NEE with the similar meteorological conditions. Finally, the half-hourly data are aggregated to make daily to annual values of NEE, RE, and GPP (= NEE-RE).

The uncertainty associated with a given gap-filling method was assessed by comparing the annual estimation of NEE, RE, and GPP in 2006 between the KoFlux and FLUXNET protocols. The comparison illustrated a good agreement with the difference of $20 \%$ for the individual carbon components, and unusual peaks of GPP and RE generated by the FLUXNET protocol during the non-growing season were absent with the KoFlux protocol (data not shown). Different artificial gaps (i.e., $30 \sim 50 \%$ ) were randomly created to investigate the sensitivity to the gap-filling method for the annual estimation of NEE. The annual NEE varied about $20 \mathrm{gC} \mathrm{m}^{-2} \mathrm{y}^{-1}$ with the increasing artificial gaps (Hong et al., 2009). These results suggest that the artificial errors associated with the gap-filling are relatively minor in the estimation of annual carbon budget in this study.

\subsection{Energy balance}

The energy balance at the two sites was assessed using the Energy Balance Ratio (EBR $=\sum\left(R_{\mathrm{n}}-G\right) / \sum(L E+H)$, where $G, L E$, and $H$ are ground, latent, and sensible heat fluxes, respectively; Wilson et al., 2000), which was calculated from the daily integrated values of individual energy balance components (Fig. 2). The EBR varied from 0.5 to 1.8 with an average of 0.68 at the GDK site and from 0.7 to 2.0 with an average of 0.92 at the HFK site throughout the measurement periods (see Kang et al., 2009 for more details). The values of the EBR were within the ranges reported from other forest and agricultural sites (e.g., Wilson et al., 2000). The water balance at the site is an additional constraint to examine the quality of flux measurements by the same eddy covariance system. At the GDK site, the water balance was closed within $10 \%$, providing more assurance in the quality of the flux measurements used in this study (see Fig. 3 in Kang et al., 2009). 


\section{Result}

\subsection{Climate conditions}

The annual averages of $T_{\mathrm{a}}$ at the GDK and HFK sites had a minor year-to-year variation $\left(<0.5^{\circ} \mathrm{C}\right)$ during the measurement period. Annual precipitation $(P)$ varied from 1356 to $1625 \mathrm{~mm}$ with an average of $1487 \mathrm{~mm}$ at the GDK site, and from 1060 to $1585 \mathrm{~mm}$ with an average of $1341 \mathrm{~mm}$ at the HFK site. Intensive rainfalls occurred mainly during the summer season including Changma, defined as the intensive rainy spell in summer (mostly from late June to July), accounting 53-74\% of the annual $P$. The annual sums of $R_{\mathrm{g}}$ at both sites also showed a minor variation (of $<200 \mathrm{MJ} \mathrm{m}^{-2}$ ) from year to year. The annual mean of surface Soil Water Content (SWC) also changed little at the GDK site, whereas that of SWC in 2008 was low at the HFK site, reflecting the decreased rainfalls and the absence of typhoons during and after the summer monsoon.

The 30-year normals of $T_{\mathrm{a}}$ and $P$ are respectively $9.9^{\circ} \mathrm{C}$ and $1344 \mathrm{~mm}$ at the GDK site and $13.3^{\circ} \mathrm{C}$ and $1306 \mathrm{~mm}$ at the HFK site. In general, $T_{\mathrm{a}}$ was about $2-3{ }^{\circ} \mathrm{C}$ higher and $P$ was $10-15 \%$ higher than the normal for both sites. Monthly deviations of $P$ and $R_{\mathrm{g}}$ from their 30-year normals are shown in Fig. 3. At the GDK site, $P$ showed positive deviations during Changma but negative deviations after Changma from August to October in 2006 and 2008, causing the corresponding variations in SWC. On the contrary, the year of 2007 had a negative deviation during Changma, resulting in lower SWC at the site, and had a positive deviation in August and September due to frequent typhoons. The HFK site showed a positive deviation during Changma for all three years. In 2008, however, the lower $P$ from July to September than the normal (by $\sim 20 \%$ ) resulted in a drought in the fall. The deviation of monthly averaged $R_{\mathrm{g}}$ generally followed the opposite patterns of $P$ deviation. Monthly $T_{\mathrm{a}}$ was mostly higher than the normal at both sites (not shown).

The overall seasonal trend of PAI was similar each year at the GDK site: the leaf-out occurred in early to mid April and the leaves grew to the full size around mid June with PAI of 5-6 (Fig. 4). The continuous rainfall events of substantial amount and intensity in the summer resulted in a decrease of PAI to almost 4 by breaking tree branches and uprooting trees where the ground soil became soft. After the leaf-fall, PAI declined to about 1.2 throughout the winter, indicating that the maximum LAI (i.e., the difference between the maximum PAI in June and the wintertime PAI) was around 4 to 5. The differences in PAI between the different years seen in Fig. 4 (e.g., consistently higher PAI in 2006, the earlier leafout with rapidly increasing PAI in the spring of 2008) were subtle but noteworthy because they were accurately manifested in the observed NEE by eddy covariance measurements. At the HFK site, the variation of MODIS LAI was related with the management practice (i.e., two crop rotation) conducted by the local community. MODIS LAI reached

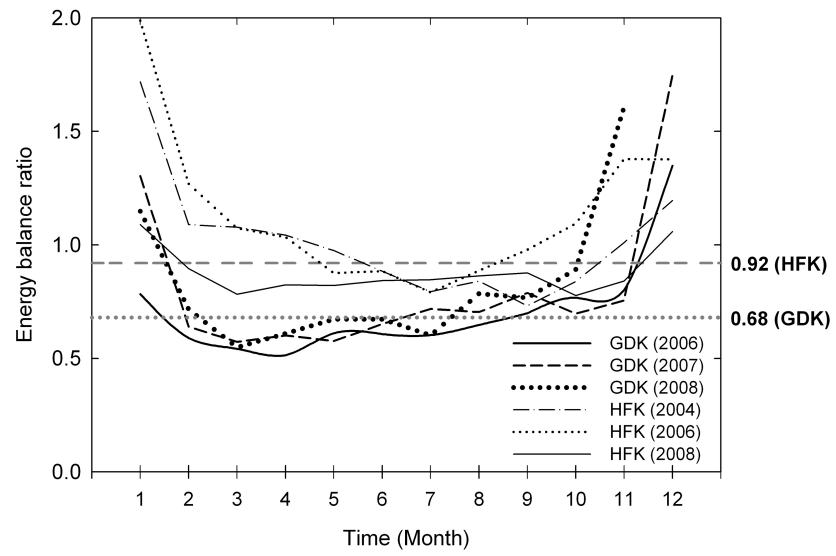

Fig. 2. Monthly Energy Balance Ratio (EBR) at the GDK site (2006 to 2008) and at the HFK site (2004, 2006, and 2008). The shortdotted line represents the annual average value for the GDK site, whereas the long-dotted line represents the annual average for the HFK site.

around 1 in late April but declined to $<1$ in late May to early June, corresponding to the growth of barley in the spring and the harvest in late May. MODIS LAI in June 2004 and 2006 showed an earlier increase than in June 2008, reflecting the different timing of rice transplanting each year. During the peak growth stage of rice and other crops (in July to August), MODIS LAI showed the maximum of 3 4 and the year 2008 had a higher LAI than 2006. The typical values of maximum LAI reported for croplands are on average around 4 (e.g., Scurlock et al., 2001).

\subsection{Seasonal and interannual variations of NEE, RE, and GPP}

GDK site: Each year, the daily NEE demonstrated a bimodal seasonal pattern with a mid-season depression in carbon uptake, as has been reported by Kwon et al. (2009). Until the leaf-out in mid April, the forest ecosystem was a carbon source. With rapidly increasing LAI in May to early June, NEE reached its first peak of carbon uptake ( -6 to $\left.-4 \mathrm{gC} \mathrm{m}^{-2} \mathrm{~d}^{-1}\right)$. Then in June, the mid-season depression in NEE started and turned the forest ecosystem to a weak carbon sink or even a carbon source $\left(\sim 2 \mathrm{gC} \mathrm{m}^{-2} \mathrm{~d}^{-1}\right)$ during the summer monsoon. As the forest recovered the strength of carbon uptake in September, the second peak of NEE occurred but was less pronounced $\left(-2\right.$ to $-3 \mathrm{gC} \mathrm{m}^{-2} \mathrm{~d}^{-1}$ ) (Fig. 5). The relative contribution of the first and the second portions of carbon sink was on average 70 and $30 \%$ to the annual carbon sink strength, respectively.

The variation of RE followed the general trend of $T_{\mathrm{a}}$ (and soil temperature, not shown) with its maximum in July and August. A bimodal pattern was not observed but the magnitude of RE decreased during the mid-season depression due to either excessive rainfalls (and thus high SWC) or 


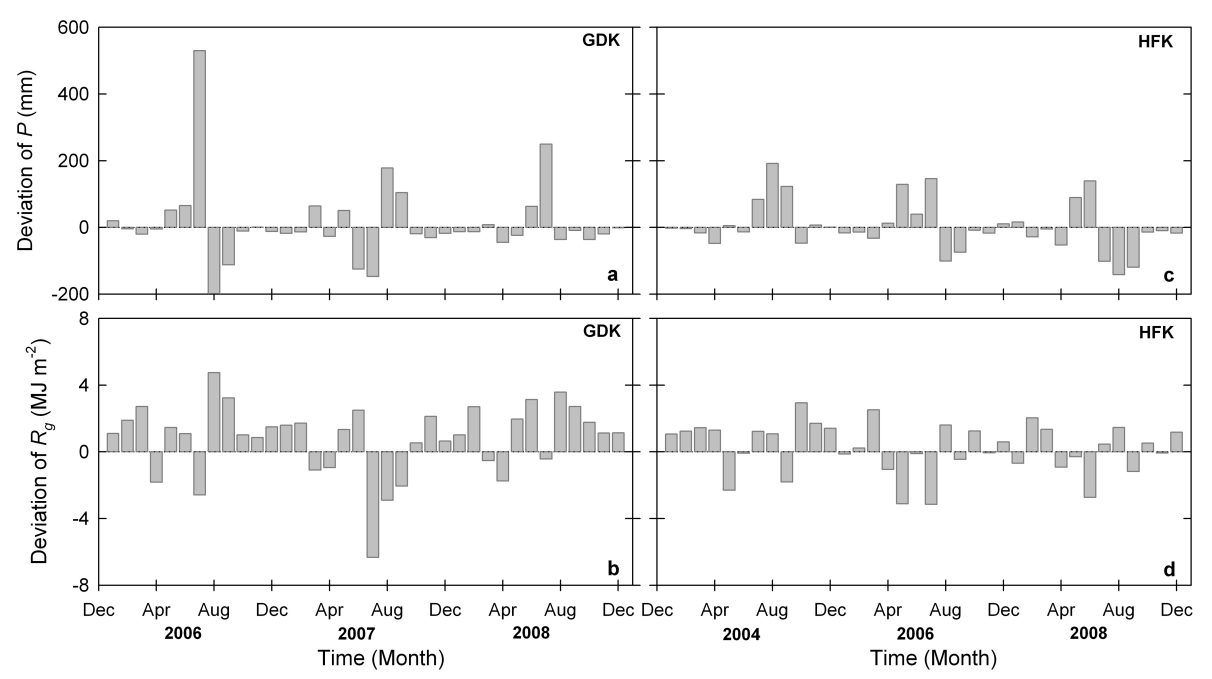

Fig. 3. Deviation of cumulative monthly precipitation $(P)$ from the climate normal sum and deviation of mean monthly solar radiation $\left(R_{\mathrm{g}}\right)$ from the climate normal mean at the GDK and HFK sites. The climate normal was calculated using the data from 1971-2000.
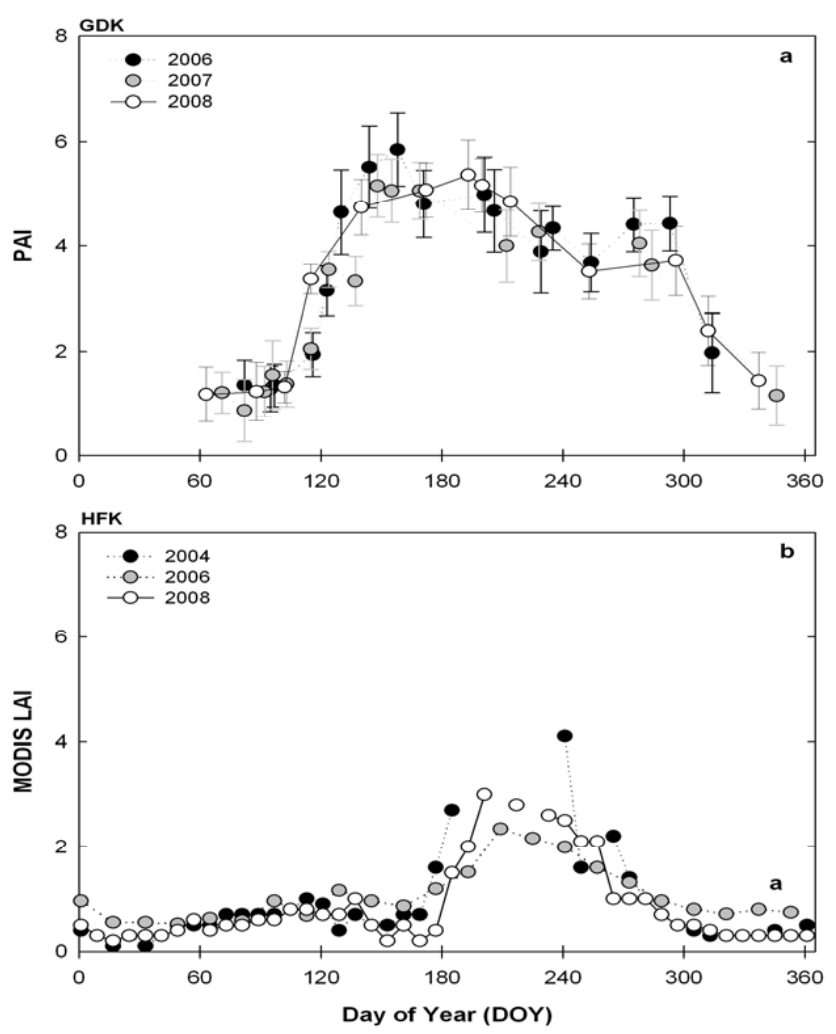

Fig. 4. Seasonal variation of Plant Area Index (PAI) at the GDK site (2006 to 2008) and Leaf Area Index (LAI) at the HKF site (2006 and 2008). Closed circles with a dotted line are for the GDK site measured from a plant canopy analyzer (LAI-2000) and the error bar indicates standard deviation of each measurement. Open circles with a dotted line are for the HKF site obtained from moderateresolution imaging spectroradiometer (MODIS). lack of rainfalls (and thus dry spell with low SWC) (e.g., Chae, 2008). The influence of higher $T_{\mathrm{a}}$ in March and April in 2008 was reflected in an early and rapid rise in RE. As shown in the trend of NEE, GPP manifested a bimodal pattern with the first peak of 6 to $8 \mathrm{gC} \mathrm{m}^{-2} \mathrm{~d}^{-1}$ in Mayearly June and the second peak of $4 \mathrm{gC} \mathrm{m}^{-2} \mathrm{~d}^{-1}$ in September and October. During the mid-season depression, GPP decreased substantially to $<2 \mathrm{gC} \mathrm{m}^{-2} \mathrm{~d}^{-1}$.

HFK site: The annual patterns of NEE were similar for the three years. The farmland was a carbon source until February and became a sink (of -4 to $-1 \mathrm{gC} \mathrm{m}^{-2} \mathrm{~d}^{-1}$ ) from April to May during the growing season of spring barley (i.e., the first peak). With the barley harvest followed by weeding and sowing, the farmland turned into a carbon source of 1 to $3 \mathrm{gC} \mathrm{m}^{-2} \mathrm{~d}^{-1}$ in late May to early July (i.e., the mid-season depression). During the growing season of rice and other crops in the summer and fall, NEE reached the second peak of carbon uptake of $-6 \mathrm{gC} \mathrm{m}^{-2} \mathrm{~d}^{-1}$. After the rice harvest in late September to early October, the farmland remained as a carbon source. The relative contribution of the first and second peaks to the annual carbon sink strength was on average 10 and $90 \%$, respectively. As observed at the GDK site, the HFK site also exhibited a bimodality but the patterns, magnitudes, and mechanisms were different. The interannual variation of RE was similar for the three years, following the trend of $T_{\mathrm{a}}$. Consequentially, the variation of GPP also showed the similar bimodal patterns each year.

\subsection{Annual carbon budget}

GDK site: Annually integrated values of carbon budget components varied from year to year, ranging from -246 to $66 \mathrm{gC} \mathrm{m}^{-2} \mathrm{y}^{-1}$ for NEE, from 947 to 1034 for $\mathrm{RE}$, and from 1020 to $1281 \mathrm{gC} \mathrm{m}^{-2} \mathrm{y}^{-1}$ for GPP (Table 1). For the three 
years studied here, the mean values of NEE, RE, and GPP were respectively $-84 \mathrm{gC} \mathrm{m}^{-2} \mathrm{y}^{-1}, 1028 \mathrm{gC} \mathrm{m}^{-2} \mathrm{y}^{-1}$, and $1113 \mathrm{gC} \mathrm{m}^{-2} \mathrm{y}^{-1}$, indicating that about $8 \%$ of GPP was sequestered by this forest ecosystem.

HFK site: The annual NEE, RE, and GPP ranged from -172 to $10 \mathrm{gC} \mathrm{m}^{-2} \mathrm{y}^{-1}$, from 1222 to $1293 \mathrm{gC} \mathrm{m}^{-2} \mathrm{y}^{-1}$, and from 1212 to $1465 \mathrm{gC} \mathrm{m}^{-2} \mathrm{y}^{-1}$, respectively (Table 2). The three-year average of GPP was $1321 \mathrm{gC} \mathrm{m}^{-2} \mathrm{y}^{-1}$, which was about $20 \%$ greater than that at the GDK site. However, the averaged RE (of $1263 \mathrm{gC} \mathrm{m}^{-2} \mathrm{y}^{-1}$ ) was as large as that of GPP, resulting in the averaged NEE (of $-58 \mathrm{gC} \mathrm{m}^{-2} \mathrm{y}^{-1}$ ) lower than that of the forest. This result shows that RE is an important determinant of the annual NEE in this farmland ecosystem.

\subsection{Environmental Effects on NEE, RE, and GPP}

The influence of environmental variables on carbon budget components was assessed by examining the relationships between their monthly anomalies. Daily anomaly of each variable was calculated from the 3-year daily mean and used to calculate correlation coefficient for each month.

GDK site: A strong positive correlation between $R_{\mathrm{g}}$ and GPP was observed, indicating that a positive $R_{\mathrm{g}}$ anomaly (a high $R_{\mathrm{g}}$ ) yielded a positive GPP anomaly (a high GPP) and vice versa (Fig. 6a). The relationship between the $R_{\mathrm{g}}$ and NEE anomalies was negatively correlated, suggesting that, for example, a negative $R_{\mathrm{g}}$ anomaly (a decreased $R_{\mathrm{g}}$ ) induced a positive NEE anomaly (an increased NEE and thus a reduced carbon uptake). The correlations between the anomalies of $R_{\mathrm{g}}$ and both GPP and NEE were significant throughout the year with a highest correlation in July. In contrast, no significant relationship was detected between $R_{\mathrm{g}}$ and RE anomalies except the winter. Generally, the GPP anomaly had a weak correlation with $T_{\mathrm{a}}$ anomaly (Fig. 6b). The NEE anomaly had a strong correlation with the $T_{\mathrm{a}}$ anomaly in the winter but no significant correlation in other seasons. A significant correlation between the $T_{\mathrm{a}}$ and $\mathrm{RE}$ anomalies was seen throughout the year. The wintertime NEE was determined by RE and thus the response of its anomaly to the $T_{\mathrm{a}}$ anomaly was similar to that of RE. The SWC anomaly had a weak or insignificant correlation with the anomalies of the carbon budget components because the forest was mostly not water-limited (Fig. 5). Overall, these results suggest that the variation of GPP and NEE were controlled by $R_{\mathrm{g}}$ whereas that of RE was controlled mainly by $T_{\mathrm{a}}$ at the GDK site. The influence of SWC on GPP, NEE, and RE was minor.

HFK site: Similarly to the GDK site, Fig. 6d shows a strong positive correlation between the $R_{\mathrm{g}}$ and GPP anomalies, a strong negative correlation between the $R_{\mathrm{g}}$ and NEE anomalies, and no significant correlation between the $R_{\mathrm{g}}$ and $\mathrm{RE}$ anomalies. However, the $T_{\mathrm{a}}$ anomaly was significantly correlated with those of the carbon budget components (Fig. 6e). Particularly during the rice growth period (from June to September), there was a strong positive
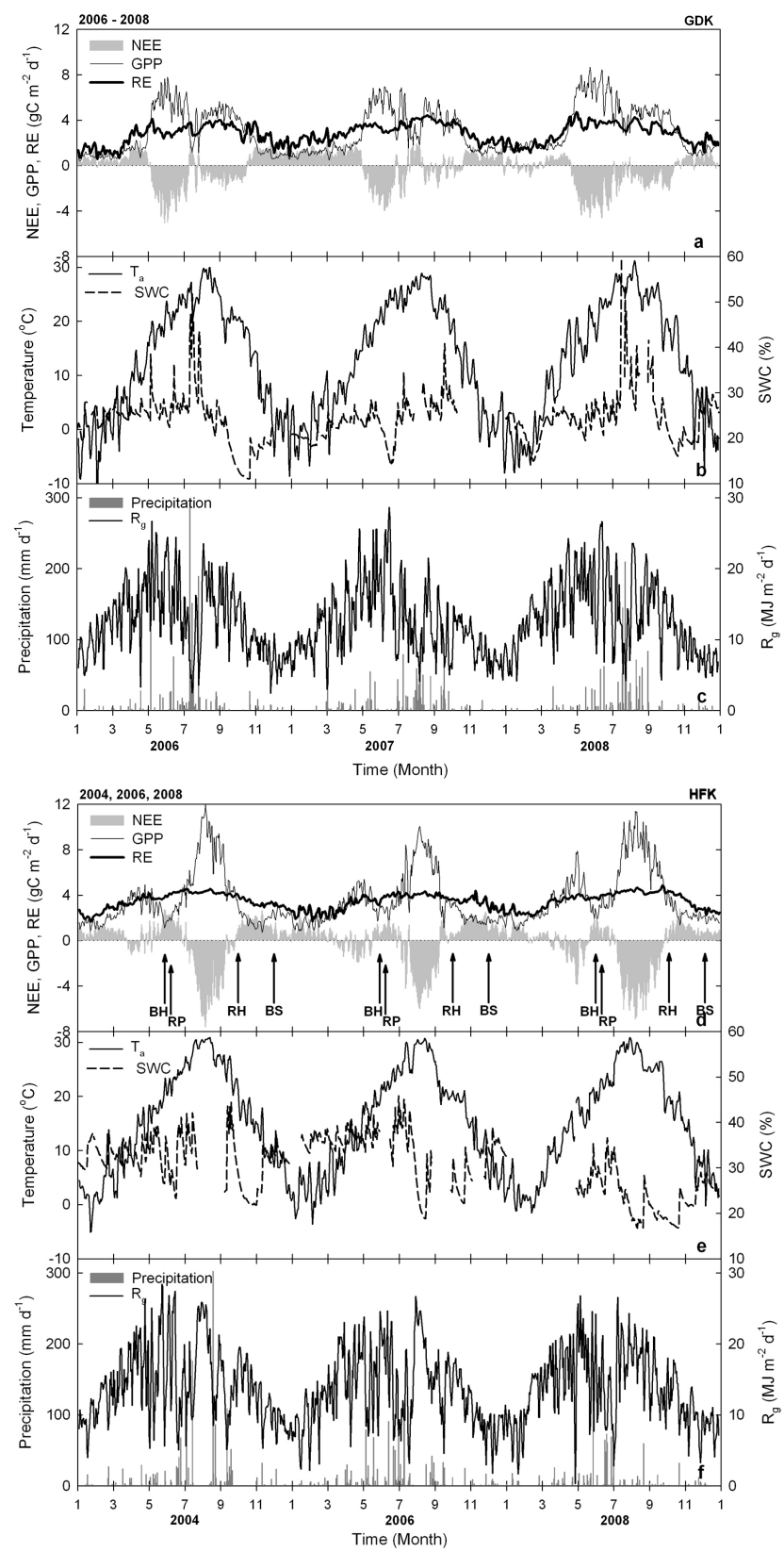

Fig. 5. Seasonal variation of Net Ecosystem Exchange (NEE), Gross Primary Productivity (GPP), Ecosystem Respiration (RE), air temperature $\left(T_{\mathrm{a}}\right)$, Soil Water Content (SWC), precipitation, and solar radiation $\left(R_{\mathrm{g}}\right)$ at the GDK site (2006 to 2008) and the HFK site (2004, 2006, and 2008). In the HFK site, the arrows represent the main management interventions: BS: Barely Sowing, BH: Barely Harvest, RP: Rice Planting, RH: Rice Harvest. Note that the management interventions occurred over several consecutive days not at an exact point where the arrows pointed.

correlation between the $T_{\mathrm{a}}$ and GPP anomalies and a strong negative correlation between the $T_{\mathrm{a}}$ and NEE anomalies. Furthermore, the correlations between the SWC and RE anomalies were significant through the year. We concluded that 
Table 1. Seasonal and annual budgets of Net Ecosystem $\mathrm{CO}_{2}$ Exchange (NEE), Gross Primary Production (GPP), and Ecosystem Respiration (RE) for the GDK and HFK sites.

\begin{tabular}{|c|c|c|c|c|c|c|c|c|c|c|}
\hline & \multirow[t]{2}{*}{ Year } & \multicolumn{3}{|c|}{2006} & \multicolumn{3}{|c|}{2007} & \multicolumn{3}{|c|}{2008} \\
\hline & & NEE & GPP & $\mathrm{RE}$ & $\mathrm{NEE}$ & GPP & $\mathrm{RE}$ & NEE & GPP & $\mathrm{RE}$ \\
\hline \multirow[t]{6}{*}{ GDK } & Winter & 59 & 74 & 133 & 88 & 109 & 197 & 16 & 148 & 164 \\
\hline & Spring & -13 & 245 & 233 & 31 & 254 & 284 & -73 & 358 & 285 \\
\hline & Summer & -121 & 422 & 302 & -75 & 412 & 337 & -154 & 490 & 336 \\
\hline & Fall & 1 & 279 & 280 & 22 & 261 & 284 & -36 & 285 & 249 \\
\hline & Annual Sum & -73 & 1020 & 947 & 66 & 1037 & 1103 & -246 & 1281 & 1034 \\
\hline & Year & & 2004 & & & 2006 & & & 2008 & \\
\hline \multirow{5}{*}{ HFK } & Winter & 66 & 166 & 231 & 86 & 142 & 229 & 56 & 169 & 224 \\
\hline & Spring & 36 & 286 & 322 & -16 & 310 & 294 & -39 & 371 & 333 \\
\hline & Summer & -175 & 567 & 392 & -145 & 514 & 369 & -208 & 594 & 386 \\
\hline & Fall & 60 & 266 & 327 & 85 & 247 & 332 & 19 & 331 & 350 \\
\hline & Annual Sum & -13 & 1287 & 1274 & 10 & 1212 & 1222 & -172 & 1465 & 1293 \\
\hline
\end{tabular}

Unit of NEE, RE, and GPP is $\left[\mathrm{gC} \mathrm{m}^{-2}\right.$ ] per season or year.

Months for each season are January, February, and December for winter, March to May for spring, June to August for summer, and September to November for fall.
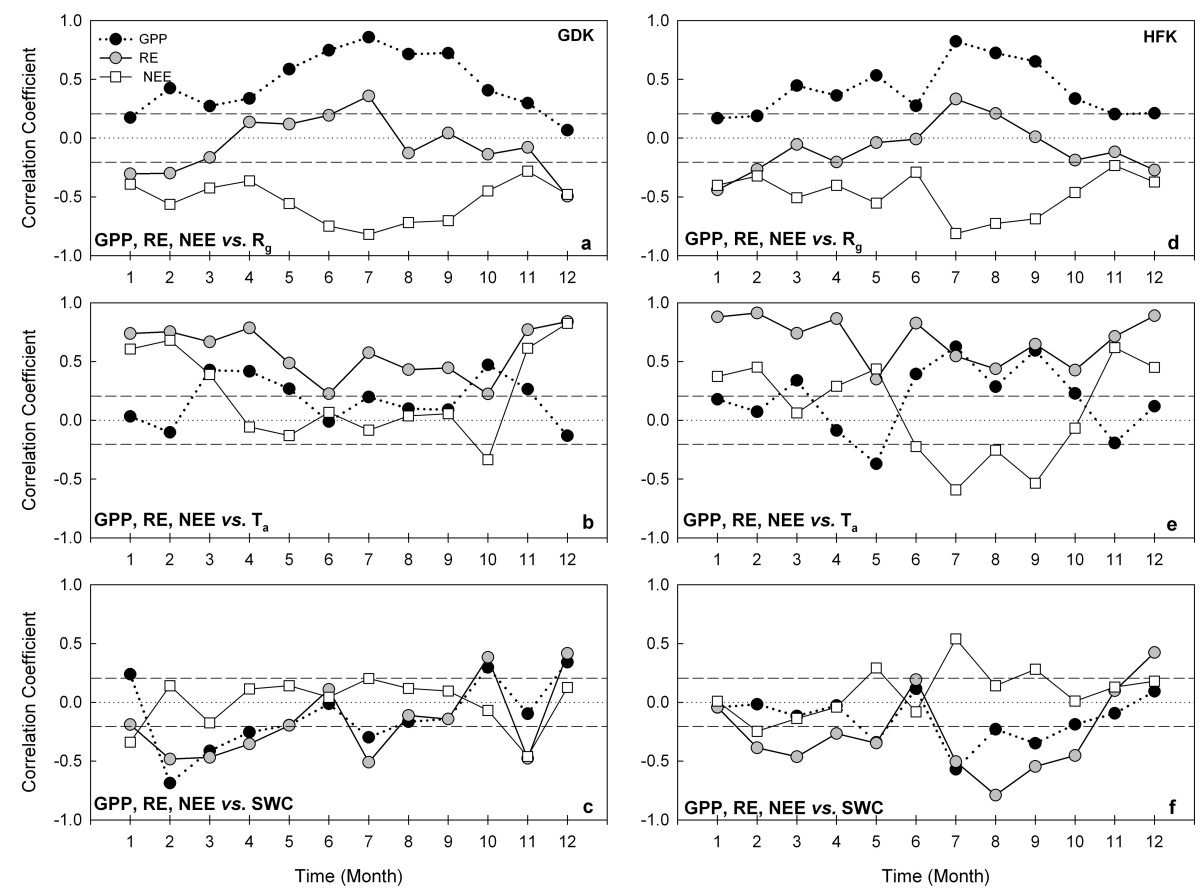

Fig. 6. Correlation of anomalies in environmental conditions (solar radiation, $R_{\mathrm{g}}$, air temperature, $T_{\mathrm{a}}$, and Soil Water Content, SWC) and carbon budget components. The long dashed lines represent critical values of correlation coefficients at the $95 \%$ confidence interval with $n=90$ for each month. 
the variations of GPP, RE, and NEE at the HFK site were affected by all three variables (i.e., $R_{\mathrm{g}}, T_{\mathrm{a}}$, and $\mathrm{SWC}$ ) especially during the growing season of rice.

\section{Discussion}

The observed mid-season depressions of NEE at the GDK site are mainly the results of intensive and consecutive rainfalls that reduced $R_{\mathrm{g}}$ during the summer monsoon (Fig. 8). Accordingly, the duration of the mid-season depression shifted with changes in the frequency and intensity of rainfall events. For example, even after the typical Changma in July, unusually heavy rainfalls continued in August and September in 2007, which produced a prolonged and pronounced mid-season depression in NEE (Fig. 5). Consequently, the forest turned into a carbon source. In 2008, the less pronounced mid-season depression of NEE (resulting in a moderate carbon sink strength) was associated with less rainy days in June-August (e.g., 45 days in 2006, 46 days in 2007, and 38 days in 2008) with more intermittent rainfall patterns (e.g., 12 consecutive rainy days in 2006, 14 days in 2007, and 8 days in 2008), which resulted in higher $R_{\mathrm{g}}$.

At the HFK site, the mid-season depression of NEE was associated more with management intervention throughout the growing seasons of barley, rice, and other crops. Similar behavior of cropland responding to human intervention was also found in Aubinet et al. (2009). Their study indicated the significance of intercropping and human interventions on carbon loss (e.g., an increased RE after harvest, a decreased GPP after herbicide application), in which the 4-year rotation of crops turned the cropland into a carbon source. Furthermore, the rice at the early growth stage under irrigated conditions at the HFK site seemed less affected by the reduced radiation especially during Changma. Despite the local droughts encountered during the latter half of 2008 due to the decline in precipitation and the absence of typhoons (Fig. 3), the patterns and magnitudes of NEE differed marginally from those observed in previous years. This was due to the human intervention through irrigation to maintain rice growth under well-watered conditions.

A distinct depression in NEE in the middle of the growing season has been seldom reported in other regions of the monsoon Asia. Hirano et al. (2003) and Hirata et al. (2008) reported a reduced NEE in August in their multi-year observations from a larch plantation in Tomakomai, Japan. They attributed, however, the reduced NEE to the enhanced RE with increased soil temperature. Saigusa et al. (2005) presented the decreased carbon uptake during the rainy season (in July) in a secondary deciduous forest in Takayama, Japan but the magnitude of decrease was not as prominent as seen in our study. We examined the seasonal patterns of monthly solar radiation and precipitation for these two sites obtained from the Japan Meteorological Agency (http: //www.data.jma.go.jp/). Long-term solar radiation data were

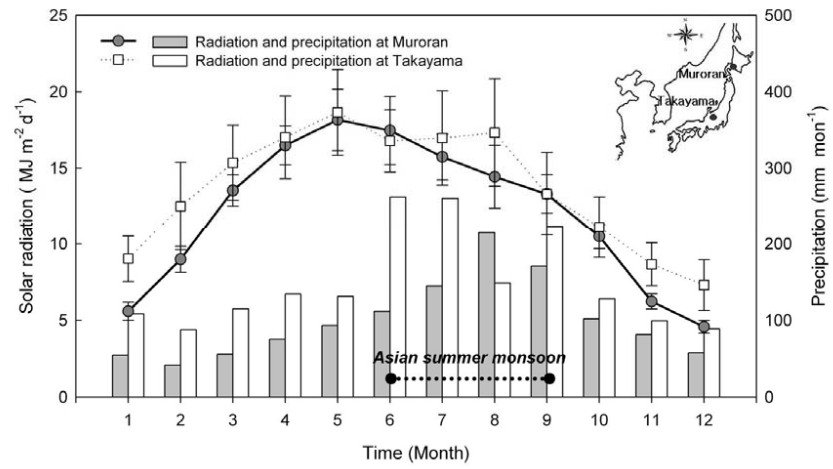

Fig. 7. Variations of averaged daily solar radiation per month at Muroran $\left(42^{\circ} 32^{\prime} \mathrm{N}\right.$ : $\left.140^{\circ} 97^{\prime} \mathrm{E}\right)$ and Takayama $\left(36^{\circ} 9^{\prime} \mathrm{N}\right.$ : $\left.137^{\circ} 15^{\prime} \mathrm{E}\right)$ in Japan. The period of solar radiation data used was 1973-2003 for Muroran and 1961-1973 for Takayama (http://www. data.jma.go.jp/).

not available at Tomakomai and the data at Muroran (i.e., the nearest weather station at about $70 \mathrm{~km}$ from Tomakomai) were used for the analysis. Precipitation considerably increased at both sites during the Asian summer monsoon (Fig. 7). Only the Takayama station demonstrated a weak bimodal seasonality in $R_{\mathrm{g}}$ associated with the summer monsoon. The reductions in $R_{\mathrm{g}}$ at both sites were, however, not as distinct as those observed at the GDK site reported in this study.

The causes of the observed mid-season depression in NEE include, inter alia, reduction in GPP and NEE under low light conditions, increase in RE under warmer conditions, reduction in RE under anaerobic soil conditions with excessive soil moisture, and defoliation under heavy rainfalls. We have selected the rainy periods from June to August with precipitation $>5 \mathrm{~mm} \mathrm{~d}^{-1}$ and $R_{\mathrm{g}}<20 \mathrm{MJ} \mathrm{m}^{-2} \mathrm{~d}^{-1}$, and analyzed the influence of environmental conditions on GPP, RE, and NEE (Fig. 8). The analysis was conducted only for the GDK site where the effect of precipitation on carbon budget components was prominent. GPP had a strong positive relationship with $R_{\mathrm{g}}$ (with $r^{2}=0.70$ ), showing a large variation of GPP from 1.5 to $8.0 \mathrm{gC} \mathrm{m}^{-2} \mathrm{~d}^{-1}$ while $R_{\mathrm{g}}$ varied from 1 to $20 \mathrm{MJ} \mathrm{m}^{-2} \mathrm{~d}^{-1}$. On the contrary, RE showed virtually no variation with $R_{\mathrm{g}}\left(r^{2}<0.01\right)$. At low $R_{\mathrm{g}}$, a decreased GPP that was lower than RE caused the GDK to become a carbon source (i.e., a positive NEE). GPP, RE, and NEE showed poor correlations with both $T_{\mathrm{a}}$ and SWC. In summary, the main cause of the mid-season depression of NEE observed at the GDK site was not the $T_{\mathrm{a}}$-driven increase in RE but the $R_{\mathrm{g}}$ driven decrease in GPP.

It should be noted that the periods associated with the mid-season depression reported in this study are those when the field measurements were largely missing due to rainfall events, for which the gap-filling method was employed. This might have resulted in biases in the estimation of carbon budget component, especially when the mean diurnal variation 

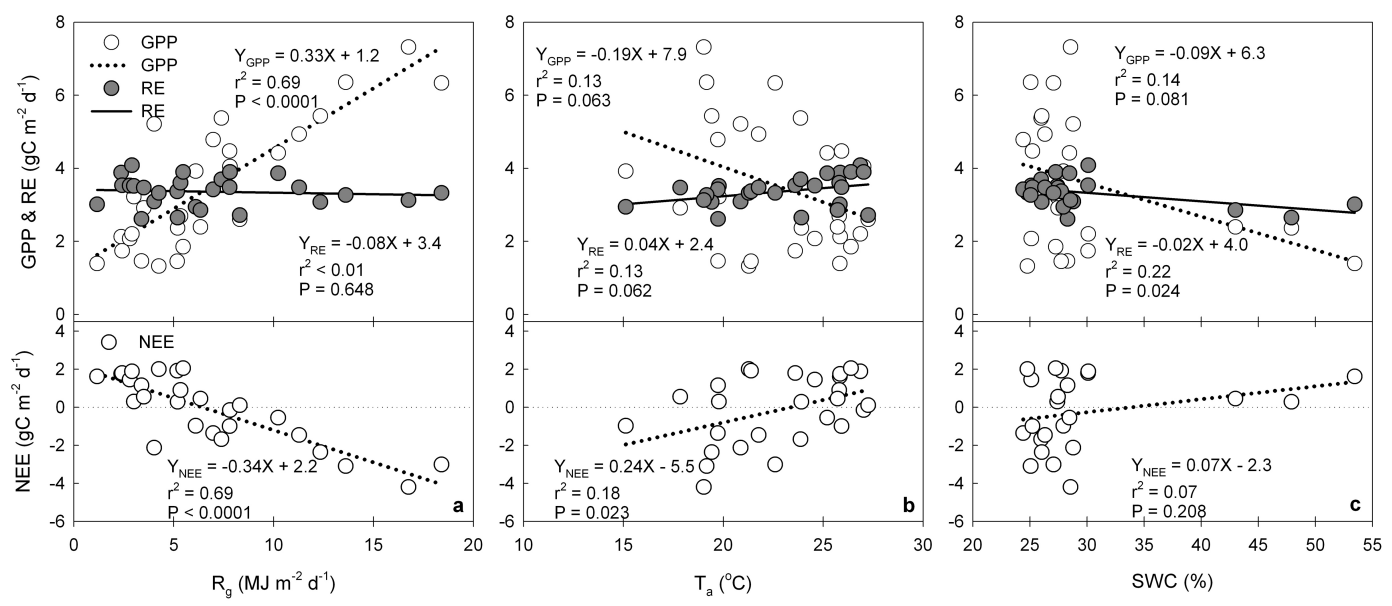

Fig. 8. The relationship between environmental conditions (solar radiation, $R_{\mathrm{g}}$, air temperature, $T_{\mathrm{a}}$, and Soil Water Content, $\mathrm{SWC}$ ) and carbon budget components during a rainy period from June to August at the GDK site from 2006 to $2009(n=27)$. $r^{2}$ and $P$ are determination of correlation and significance level, respectively.

method was used for the gap-filling because it used the data representing mostly clear and sunny conditions. Considering NEE being the subtle balance between two large carbon fluxes, the RE estimation (based on a relationship between temperature and nighttime carbon flux) may cause additional errors in ascertaining the observed mid-season depression. In order to scrutinize the processes causing mid-season depression, a careful examination is needed with independent datasets (i.e., NEE and RE) collected during the rainy periods (instead of gap-filled data). Measuring fluxes in the rain is therefore an important issue in monsoon regions, for which attempts have been made recently by employing closed-path sensors in conjunction with a modified aerodynamic method (e.g., Dias et al., 2009).

On an annual basis, the net $\mathrm{CO}_{2}$ uptake at the GDK site averaged $84 \mathrm{gC} \mathrm{m}^{-2}$ with a large variability during the study years (Table 1). Plant phenology was different to some extent for the three years. The leaf-out occurred on 12 April in 2006 and 15 April in 2007, whereas in 2008 it occurred on 8 April. The earlier leaf expansion may have yielded a longer period of a carbon uptake during the first peak. This is also supported by the rapid increase of LAI during April in 2008 (Fig. 4). The extended length of the growing season, in conjunction with the weakened mid-season depression, probably resulted in a substantial increase in carbon uptake in 2008 (Table 1 and Fig. 5). Other data, however, did not seem to support such an interpretation. For example, the annul diameter growth rates of the major species at the site were respectively 5.2 and $5.5 \mathrm{~mm} \mathrm{y}^{-1}$ in 2006 and 2007, but it was $3.44 \mathrm{~mm} \mathrm{y}^{-1}$ in 2008 (Jong-Hwan Lim, personal communication, 2009). Despite the similar growth rates in 2006 and 2007 , the annual carbon budget changed its sign from carbon sink in 2006 to source in 2007. In addition to the extended period of mid-season depression of carbon uptake, the net carbon loss in 2007 is also attributed to a lower LAI. The month-long dry spell encountered in the early summer (e.g., no rain in June) may also have played a role here (Fig. 5).

The annual NEE of the deciduous forest at the GDK site was near the low end of the ranges reported from other forests in similar latitudes in the monsoon Asia. For deciduous forests, Saigusa et al. (2005) reported the annual NEE varying from -346 to $-59 \mathrm{gC} \mathrm{m}^{-2} \mathrm{y}^{-1}$ whereas Shibata et al. (2005) reported NEE ranging from -288 to $-219 \mathrm{gC} \mathrm{m}^{-2} \mathrm{y}^{-1}$. For coniferous forests, Ohtani et al. (2005) found NEE varying from -459 to $-318 \mathrm{gC} \mathrm{m}^{-2} \mathrm{y}^{-1}$, which is similar to the range ( -424 to $-316 \mathrm{gC} \mathrm{m}^{-2} \mathrm{y}^{-1}$ ) reported by Yu et al. (2006). The farmland at the HFK site exhibited virtually a balance in carbon budget except 2008 when it became a weak carbon sink. Again, the occurrence of mid-season depression in NEE played a major role in this farmland ecosystem. On the other hand, larger magnitudes of NEE have been reported for other agricultural sites in monsoon Asia (e.g., -301 to $-102 \mathrm{gC} \mathrm{m}^{-2} \mathrm{y}^{-1}$ for rice paddies: Miyata et al., 2005 ; -318 to $-198 \mathrm{gC} \mathrm{m}^{-2} \mathrm{y}^{-1}$ for croplands: Yoshikoshi et al., 2006; Yu et al., 2006). In terms of the relationships between the major environmental factors and the annual carbon budgets over the cross-biomes (Kato and Tang, 2008), NEE, RE and GPP at both GDK and HFK sites fall onto lower ranges with given $P$ and $T_{\mathrm{a}}$ except the relationship between $\mathrm{RE}$ and $T_{\mathrm{a}}$ (Kwon et al., 2009). Due to the natural and human disturbances at the GDK and HFK sites, their lower ranges of GPP and RE are fit for the characteristics of the disturbed ecosystems based on the analysis of a global data across ecological gradient (Baldocchi, 2008). 


\section{Summary and conclusions}

We reported the seasonal and interannual variations of ecosystem carbon balance observed in the two major ecosystems in Korea, that were very sensitive to hydrometeorological changes associated with the Asian summer monsoon and the local land use management. The major findings from the three-year study periods can be summarized as follows: (1) the mid-season depression of NEE recurred every year at both forest and farmland sites; (2) the driving mechanisms of the observed mid-season depressions of NEE were different for the two ecosystems; (3) the mid-season depression at the deciduous forest site was associated with natural disturbances (i.e., the Asian summer monsoon, typhoons), whereas that in the farmland site was associated with human disturbance (i.e., land management rotating two crops); (4) the different sources of disturbance resulted in the different timing and magnitude of the mid-season depression of NEE; (5) the major cause of the mid-season depression at the GDK site was not the enhanced RE but the reduced GPP as a result of decreasing $R_{\mathrm{g}}$; (6) the lesser effect of the summer monsoon on NEE at the HFK site may have been associated with the mosaic patches of diverse farmland vegetation, which provide resilience to natural disturbance and/or with human interventions through adaptive management such as drainage and irrigation; and finally (7) the projection of increased natural and human disturbances is likely to change the strength and the distribution of carbon sinks and sources in East Asia and to alter the role of terrestrial ecosystems in the context of regional carbon budget - a process not fully captured by carbon cycle models.

Acknowledgements. This study is supported by the A3 Foresight Program of Korea Science and Engineering Foundation, the Long-term Ecological Study and Monitoring of Forest Ecosystem Project of Korea Forest Research Institute, a grant (Code: 1-8-3) from Sustainable Water Resource Research Center of 21st Century Frontier Research Program, the Eco-Technopia 21 Project of Ministry of Environment, and the BK21 program from the Ministry of Education, Science and Technology of Korea. We appreciate the reviewers' critical yet constructive comments, allowing us to improve the manuscript.

Edited by: T. Hirano

\section{References}

Allard, V., Ourctval, J. M., Rambal, S., Joffre, R., and Rocheteau, A.: Seasonal and annual variation of carbon exchange in an evergreen Mediterranean forest in southern France, Global Change Biol., 14, 714-725, 2008.

Aubinet, M., Moureaux, C., Bodson, B., Dufranne, D., Heinesch, B., Suleau, M., Vancutsem, F., and Vilret, A: Carbon sequestration by a crop over a 4-year sugar beet/winter wheat/seed potato/winter wheat rotation cycle, Agr. Forest Meteorol., 149, 407-418, 2009.
Baldocchi, D.: Breathing of the terrestrial biosphere: lessons learned from a global network of carbon dioxide flux measurement systems, Aust. J. Bot., 56, 1-26, 2008.

Chae, N.: Soil $\mathrm{CO}_{2}$ efflux in a temperate forest ecosystem under monsoon climate in Northeast Asia, Doctoral dissertation, Yonsei University, 157 pp., 2008.

Dias, L. N., Hong, J., Leclerc, Y. M., Black, T. A., Nesic, Z., and Kirshnan, P.: A simple method of estimating scalar fluxes over forests, Bound.-Lay. Meteorol., 132, 401-414, 2009.

Dunn, A. L., Barford, C. C., Wofsy, S. C., Goulden, M. L., and Daube, B. C.: A long-term record of carbon exchange in a boreal black spruce forest: means, responses to interannual variability, and decadal trends, Global Change Biol., 13, 577-590, 2007.

Esser, G.: Contribution of monsoon Asia to the carbon budget of the biosphere, past and future, Vegetatio, 121, 175-188, 1995.

$\mathrm{Fu}, \mathrm{C}$. B. and Wen, G.: Variation of ecosystems in East Asia in association with the seasonal, interannual and interdecadal variations of monsoon climate, Climatic Change, 43, 477-494, 1999.

Gilmanov, T., Svejcar, T., Johnson, D., Angell, R., Saliendra, N., and Wylie, B.: Long-term dynamics of production, respiration, and net $\mathrm{CO}_{2}$ exchange in two sagebrush-steppe ecosystems, Rangeland Ecol. Manag., 59, 585-599, 2006.

Gu, L., Falge, E. M., Boden, T., Baldocchi, D. D., Black, T. A., Saleska, S. R., Suni, T., Verma, B., Vesala, T., Wofsy, S. C., and $\mathrm{Xu}, \mathrm{L}$.: Objective threshold determination for nighttime eddy flux filtering, Agr. Forest Meteorol., 128, 179-197, 2005.

Hirano, T., Hirata, R., Fujinuma, Y., Saigusa, N., Yamamoto, S., Harazono, Y., Takada, M., Inukai, K., and Inoue, G.: $\mathrm{CO}_{2}$ and water vapor exchange of a larch forest in northern Japan, Tellus B, 55, 244-257, 2003.

Hirata, R., Hirano, T., Saigusa, N., Fujinuma, Y., Inukai, K., Kitamori, Y., Takahashi, Y., and Yamamoto, S.: Seasonal and interannual variations in carbon dioxide exchange of a temperate larch forest, Agr. Forest Meteorol., 147, 110-124, 2007.

Hong, J., Kwon, H., Lim, J.-H., Byun, Y.-H., Lee, J., and Kim, J.: Standardization of KoFlux eddy-covariance data processing, Korean J. Agr. Forest Meteorol., 2, 19-26, 2009.

Kang, M., Park, S., Kwon, H., Choi, H. T., Choi, Y.-J., and Kim, J.: Evapotranspiration from a deciduous forest in a complex terrain and a heterogeneous farmland under monsoon climate, AsiaPacific J. Atmos. Sci., 45, 175-191, 2009.

Kato, T. and Tang, Y.: Spatial variability and major controlling factors of $\mathrm{CO}_{2}$ sink strength in Asian terrestrial ecosystems: evidence from eddy covariance data, Global Change Biol., 14, 2333-2348, 2008.

Kwon, H. J., Oechel, W. C., Zulueta, R. C., and Hastings, S. J.: Effects of climate variability on carbon sequestration among adjacent wet sedge tundra and moist tussock tundra ecosystems, J. Geophys. Res., 111, G03014, doi:10.1029/2005JG000036, 2006.

Kwon, H., Park, T.-Y., Hong, J., Lim, J.-H., and Kim, J.: Seasonality of Net Ecosystem Carbon Exchange in Two Major Plant Functional Types in Korea, Asia-Pacific J. Atmos. Sci., 45, 149163, 2009.

Lee, D., Kim, J., Kim, S.-J., Moon, S.-K., Lee, J., Lim, J.-H., Son, Y., Kang, S., Kim, S., Kim, K., Woo, N., Lee, B., and Kim, S.: Lessons from cross-scale studies of water and carbon cycles in the Gwangneung forest catchment in a complex landscape of monsoon Korea, Korean J. Agr. Forest Meteorol., 9, 149-160, 2007. 
Li, S.-G., Asanuma, J., Eugster, W., Kotani, A., Liu, J.-J., Urano, T., Oikawa, T., Davaa, G., Oyunbaatar, D., and Sugita, M.: Net ecosystem carbon dioxide exchange over grazed steppe in central Mongolia, Global Change Biol., 11, 1941-1955, 2005.

Lim, J. H., Shin, J. H., Jin, G. Z., Chun, J. H., and Oh, J. S.: Forest stand structure, site characteristics and carbon budget of the Kwangneung natural forest in Korea, Korean J. Agr. Forest Meteorol., 5, 101-109, 2003.

Lloyd, J. and Taylor, J. A.: On the temperature dependence of soil respiration, Funct. Ecol., 8, 315-323, 1994.

Ma, S., Baldocchi, D. D., Xu, L., and Hehn, T.: Inter-annual variability in carbon dioxide exchange of an oak/grass savanna and open grassland in California, Agr. Forest Meteorol., 147, 157171, 2007.

McGuire, A. D., Sitch, S., Clein, J. S., Dargaville, R., Esser, G., Foley, J., Heimann, M., Joos, F., Kaplan, J., Kicklighter, D. W., Meier, R. A., Melillo, J. M., Moore III, B., Prentice, I. C., Ramankutty, N., Reichenau, T., Schloss, A., Tian, H., Williams, L. J., and Wittenberg, U.: Carbon balance of the terrestrial biosphere in the twentieth century: analyses of $\mathrm{CO}_{2}$, climate and land-use effects with four process-based ecosystem models, Global Biogeochem. Cy., 15, 183-206, 2001.

Melillo, J. M., McGuire, A. D., Kicklighter, D. W., Moore III, B., Vorosmarty, C. J., and Schloss, A. L.: Global climate change and terrestrial net primary production, Nature, 363, 234-240, 1993.

Miyata, A., Iwata, T., Nagai, H., Yamada, T., Yoshikoshi, H., Mano, M., Ono, K., Han, G. H., Harazono, Y., Ohtaki, E., Bmaten, M. A., Inohara, S., Takimoto, T., and Saito, M.: Seasonal variation of carbon dioxide and methane fluxes at single cropping paddy fields in central and western Japan, Phyton, 45, 89-97, 2005.

Moon, S.-K., Ryu, Y., Lee, D., Kim, J., and Lim, J.-H.: Quantifying the spatial heterogeneity of the land surface parameters at the two contrasting KoFlux sites by semivariogram, Korean J. Agr. Forest Meteorol., 9, 140-148, 2007.

Myneni, R. B., Hoffman, S., Knyazikhim, Y., Privette, J. L., Glassy, J., Tian, Y., Wang, Y., Song, X., Zhang, Y., Smith, Y., Lotsch, A., Friedl, M., Morisette, J. T., Votava, P., Nemani, R. R., and Running, S. W.: Global products of vegetation leaf area and fraction absorbed PAR from year one of MODIS data, Remote Sens. Environ., 83, 214-231, 2002.

Ohtani, Y., Yasuda, Y., and Mizoguchi, Y.: Seasonal and interannual variability in net ecosystem $\mathrm{CO}_{2}$ exchange in six forest flux sites in Japan, Proceedings of the 7th International Carbon Dioxide Conference, 79-80, 2005.

Papale, D., Reichstein, M., Aubinet, M., Canfora, E., Bernhofer, C., Kutsch, W., Longdoz, B., Rambal, S., Valentini, R., Vesala, T., and Yakir, D.: Towards a standardized processing of Net Ecosystem Exchange measured with eddy covariance technique: algorithms and uncertainty estimation, Biogeosciences, 3, 571-583, 2006,

http://www.biogeosciences.net/3/571/2006/.

Reichstein, M., Falge, E., Baldocchi, D., Papale, D., Aubinet, M., Berbigier, P., Bernhofer, C., Buchmann, N., Gilmanov, T., Granier, A., Grunwald, T., Havrankova, K., Ilvesniemi, H., Janous, D., Knohl, A., Laurila, T., Lohila, A., Loustau, D., Matteucci, G., Meyers, T., Miglietta, F., Ourcival, J. M., Pumpanen, J., Rambal, S., Rotenberg, E., Sanz, M., Tenhunen, J., Seufert, G., Vaccari, F., Vesala, T., Yakir, D., and Valentini, R.: On the separation of net ecosystem exchange into assimilation and ecosystem respiration: review and improved algorithm, Global Change Biol., 11, 1424-1439, 2005.

Saigusa, N., Yamamoto, S., Murayama, S., and Kondo, H.: Interannual variability of carbon budget components in as Asia-Flux forest site estimate by long-term flux measurements, Agr. Forest Meteorol., 134, 4-16, 2005.

Scurlock, J. M., Asner, G. P., and Gower, S. T.: Worldwide historical estimates of leaf area index, 1932-2000, Oak Ridge National Laboratory, LRNL/TM-2001/268, 40 pp., 2001.

Shibata, H., Hiura, T., Tanaka, Y., Takagi, K., and Koike, T.: Carbon cycling and budget in a forested basin of southwestern Hokkaido, northern Japan, Ecol. Res., 20, 325-331, doi:10.1007/s11284005-0048-7, 2005.

van Gorsel, E., Leuning, R., Cleugh, H., Keith, H., and Suni, T.: Nocturnal carbon efflux: reconciliation of eddy covariance and chamber measurements using an alternative to the $\mathrm{u}^{*}$-threshold filtering, Tellus B, 59, 397-403, 2007.

Webb, E. K., Pearman, G. I., and Leuning, R.: Correction of flux measurements for density effects due to heat and water vapor transfer, Q. J. Roy. Meteorol. Soc., 106, 85-100, 1980.

Wilczak, J. M., Oncley, S. P., and Stage, S.: Sonic anemometer tilt correction algorithms, Bound.-Lay. Meteorol., 99, 127-150, 2001.

Wilson, K. B. and Baldocchi, D. D.: Seasonal and interannual variability of energy fluxes over a broadleaved temperate deciduous forest in North America, Agr. Forest Meteorol., 100, 1-18, 2000.

Yang, X. and Wang, M.: Monsoon ecosystems control on atmospheric $\mathrm{CO}_{2}$ interannual variability: Inferred from a significant positive correlation between year-to-year changes in land precipitation and atmospheric $\mathrm{CO}_{2}$ growth rate, Geophys. Res. Lett., 27, 1671-1674, 2000.

Yoo, J., Lee, D., Hong, J., and Kim, J.: Principles and Applications of Multi-Level $\mathrm{H}_{2} \mathrm{O} / \mathrm{CO}_{2}$ Profile Measurement System, Korean J. Agr. Forest Meteorol., 11, 27-38, 2009.

Yoshikoshi, H., Maruyama, A., and Ooba, K.: $\mathrm{CO}_{2}$ flux over the double cropping cropland (barley and soybean), Proceedings of the Joint Meeting on Environmental Engineering in Agriculture 2006, 2006.

Yu, G. R., Fu, Y., Sun, X., Wen, X., and Zhang, L.: Recent progress and future directions of ChinaFLUX, Sci. China Ser. D, 49, 1-23, 2006.

Yuan, R., Kang, M., Park, S., Hong, J., and Kim, J.: The effect of coordinate rotation on the eddy covariance flux estimation in a hilly KoFlux forest catchment, Korean J. Agr. Forest Meteorol., 9, 100-108, 2007.

Yun, K.-S., Shin, S.-H., Ha, K.-J., Kitoh, A., and Kusunoki, S.: East Asian Precipitation Change in the Global Warming Climate Simulated by a 20-km Mesh AGCM, Asia-Pacific J. Atmos. Sci., 44, 233-247, 2008. 